\title{
Yoga between Friends: an Ethnographic Exploration of an Enduring, Flexible Friendship
}

\author{
Andrew Stevenson ${ }^{1 *}$ and Rebecca Lawthom ${ }^{2}$ \\ ${ }^{1}$ Department of Psychology, Manchester Metropolitan University, England \\ ${ }^{2}$ Professor of Community Psychology, Manchester Metropolitan University, England
}

Submission: August 17, 2017; Published: November 22, 2017

*Corresponding author: Andrew Stevenson, Department of Psychology, Manchester Metropolitan University, Brooks Building 53, Bonsall Street, Manchester, England, Tel: (0044) 016-1247-2550; Email: a.stevenson@mmu.ac.uk

\begin{abstract}
This research project uses friendship ethnography interviews to show how yoga cements friendship within a single friendship pair. In exploring a practice that binds friendship, research was undertaken with participants with whom the primary researcher is already acquainted. Situating the research amongst friends, treating participants according to the ethics of friendship, draws us closer to an understanding of their bonds. The use of friendship ethnography enables the research to come closer to the non-verbal aspects of friendships that epitomize intimacy. The authors argue that friendships are practice-based, routinized and emplaced phenomena.
\end{abstract}

Keywords: Friendship; Ethnography; Yoga; Emplaced; Practice

\section{Introduction}

\section{Varieties of friendship}

Friends can be defined as somebody to talk to, to depend on and rely on for help, support, and caring, and to have fun and enjoy doing things with Rawlins [1]. A friendship is often based as much on something frequently done with another person $[2,3]$, rather than on an emotionally binding strength of affect. Indeed, a friendship may even depend on those practices that leads to its formation.

Friends come and stay together primarily through common interests, a sense of alliance and emotional affiliation [3]. Friends have been referred to as families we choose [4], or elective kin [5]. They can differ in type and vary in levels of intensity $[5,6]$. They may be simple friendships, being based on sharing a single activity, whose partners rarely meet outside of these contexts, leading to defining terms such as 'work-friend', 'church friend', 'drinking pal' or 'school friend'. Friendships can also bemultistranded affairs, based on soul-mate bonding as well as the sharing of a specific practice. Here, one respondent reflects on such a multi-stranded bond.

Friendship for me has several different levels. The best are 'close friends' - those people who, usually, I have known for a long time, and with whom I have a shared history. Heaphy \& Davies [6] Multi-level friendships may be bound into a shared history, with friends who have had good and bad times together. In such relationships, interconnectedness can comprise experiences that include "support, reciprocity, commonality, a feeling of kinship and/or being family-like" [6]. This level of friendship goes beyond one defining practice or shared belief. Friendship bonds can also be part of broad webs, set within wider occupational, leisure, or neighbourhood groups. Such interconnections bring friendship bonds closer to family ties in resemblance.

These varieties of friendship highlight the rootedness of interpersonal bonds in shared experience, yielding relationships with kin-like obligation, care, longevity, and the interdependency of wider webs of relations. In some cases, these long-term friendships may engender greater longevity than often exists in families and sexual relations Unwilling to be perceived as social chameleons flitting from one job or partner to another, men and women may come to rely on their friends to provide support and confirmation of their enduring identities [7]. Thus, friendship takes many forms and serves many functions. They can run deep, along multiple channels and beyond immediate pairs. They can rely on specific, formative activities. They can also vary 
at different times. Globally, there are many areas and practices where pairs of individuals work together for many year, such as in business, and this can yield long-term friendships. Some bonds of friendship are particularly intense when they offer support at times of transition, like bereavement or birth [8].

Close friends are those who have shared my good and bad times, and I have theirs. Heaphy \& Davies [6] yet friendships are still more binding when they incorporate present, mundane routines and broader webs of obligation, with regular opportunities to catch up and top up current friendship experiences. We share the same interests and sense of humor and we meet on a regular basis. These people I have known for over 20 years [6].

Let us end this introduction by considering a more characteristic of friendship which is especially concerning for ethnographic researchers; namely, its parallels with ethnographic fieldwork. Both practices involve gaining entry into another's space, negotiating roles, the incremental deepening of ties, and the learning of new interaction codes [3]. Friendship and fieldwork both bring dilemmas of 'getting out' [9] when the time has come to end the entanglement.

In view of these parallels, the research presented in this paper explores bonds that hold a particular friendship together using a fieldwork technique that acknowledges the family-like resemblances that exist between both friendship and research ties. Rather than studying individuals from afar [10], in a style that is often called participant observation, it makes sense here to set friendship and fieldwork side by side. Hence, the decision has been made interrupt the tendency to study friendship from a distance, and to study it amongst friends, according to the dialogical ethics of friendship [11]. With this in mind, the aim of this paper is to explore, using friendship ethnography, explore the nature of friendship bonds in one friendship pair.

\section{Method}

\section{Friendship ethnography}

Friendship ethnography involves adopting values, practices and ethics of friendship in a research context. In friendship ethnography, traditional methods of fieldwork (interviewing, observation) are set alongside friendship building practices; conversation, everyday involvement, compassion, generosity, and 'hanging out' [3]. Besides collecting data through interviews, the researcher engages in friendship practices with participants. Through this process, the relational dynamics of researcher, participant, and friend grows increasingly entangled. Tillman [3], in exploring an LGBT community, came to know her respondents interpersonally and culturally, achieving the opportunity to give compassion and devotion, to experience them emotionally and spiritually. The research involved simultaneously talking, sharing activities, exchanging material, writing and exchanging views. Thus, researcher-friendship roles wove together, each deepening the other. We argue that whilst all participants may not be considered as friends, we cannot afford to treat them as distant others either.

Friendship ethnography develops over months or years [8] and often rely on serendipity, rather than outright planning [12]; as friendships do. The method is less utilitarian than the researcher-participant relationship that prevails in traditional ethnographic work. Friendship ethnography is used to get to know others in meaningful, sustained ways $[2,10,13]$. It disrupts traditional unequal power relations between researchers and participants, reducing hierarchical separations.

Whilst ethical practices were adhered to for the present study, according to the ethical practices recommended by our university and our professional body, the nature of the friendship ethnography researcher-participant dynamic also draws on an ethics of care $[14,15]$. Participants who know that a researcher has an emotional link, are more likely to know that their confidences will not be breached, and that their interests will be honored. Similarly, when research is an endeavor approached in the spirit of friendship, emergent outputs can additionally benefit participants in terms of self-understanding and a deepening of a sense of friendship between those involved. Thus, according to this ethics of care, the present study was conducted according to friendship values, according to which the participants themselves might learn about their own friendships, as well as we as researchers learning about them.

\section{Participants}

The lead researcher worked with one friendship pair for twelve months. The lead researcher's relationship with the pairs pre-existed and outlasted this time. Time was spent interviewing and joining in with the primary practice that occupied and cemented friendship; yoga.

Participants Anne and Louise met through attending a yoga class seventeen years ago. Soon afterwards they began practicing Ashtanga Vinyasa yoga together twice weekly in each other's bedrooms, which they rearrange for the purpose. Ashtanga Vinyasa yoga was developed by Pattabhi Jois K [16] from a form of classical Indian yoga. Ashtanga, or eight limbs, incorporates asanas (physical postures) as well as breath (pranayama).

Anne and Louise opened their yoga practice to the researcher and were interviewed over dinner, cooked by the lead researcher, at Louise's house. The lead researcher has known Anne and Louise for over fifteen years and has practiced yoga with them during this period of acquaintance. The subsequent sections 
report emergent themes which were derived from thematic analysis of interview transcripts [17]. illustrating the nature of the friendship bonds as they emerged from yoga practice.

\section{Analysis: The Nature of the Friendship Bonds}

\section{Friendships as practice}

Friendship ties are often predicated on practices that bring people together, rather than on mere affection or personal empathy [3]. We may like our friends, but liking alone may not be enough for friendship. Anne and Louise met through the yoga practice that prevails in the research; yoga

Louise: We met through the yoga didn't we and we just started doing it, and then after a while it just became a habit

The dynamic, practice-based nature of their bond friendships facilitates forms of communication that go beyond 'chatting', as Anne puts it

Anne: We've spent so much time together but most of that time has been spent communicating with each other in a very different way to sitting chatting

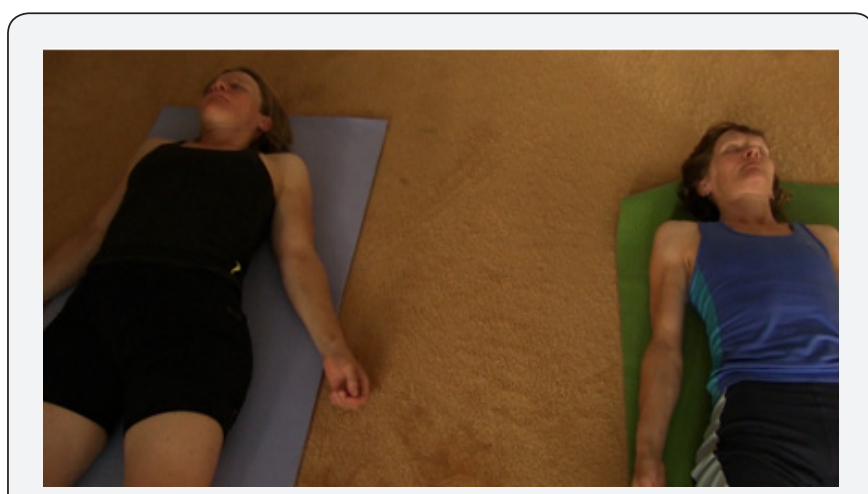

Figure 1: Anne and Louise practising side by side in silence.

As well as being illustrated by participants' quotes, the practice-based nature of this friendship is evidenced through embodiment and the senses. Figure 1 shows Louise and Anne laying together in silent relaxation, concluding their practice. For much of the research period, we see the pair wordlessly together, moving in synchrony. These notion of 'friendship doing' demonstrates the importance of practice, embodiment and synchrony for this relationship, as well as the depth of communication without speaking that each of these bonds thrives on.

\section{Friendship routines}

Multilayered friendships that revolve around shared practices are more adhesive still when they are acted out as part of a regular routine [6]. Regular, weekly or even daily meetings demonstrate the importance of the mundane present in the maintenance of friendship. Louise and Anne share a routine for their meetings, and have done for over seventeen years.

Anne: We've always maintained it on a Sunday and I think for me there must be something about being brought up Catholic and going to church on a Sunday.

The daily, weekly, annual rhythms of friendship add the weight of the present to their accumulated longevity. The mundane regularity of practising friendship together binds affective bonds and prompts the occasional thought about what might happen if these routines should for some reason cease. Here, Louise and Anne dare to contemplate their friendship without the routine of yoga

Anne: The yoga is the way we have connected and that's a big part of both our lives

Louise: I can't imagine our relationship without the yoga. I can't imagine just knowing you and not doing the yoga with you.

Ending the routine would mean the end of a large part of the relationship. It would also constitute an unwelcome interruption to a weekly cycle, bringing about what Heaphy \& Davies [6] refer to as a detrimental effect on daily living.

\section{Friendships in improvised places}

This friendship bond has been enacted in improvised spaces that were designed for other purposes. The pair is 'making do', transforming bedrooms and living rooms into meaningful friendship places. Here, Anne explains how she and Louise ritually turn their bedrooms into yoga spaces

Anne: You need a reasonable amount of space, but it does mean preparing the space, which is fine. I quite enjoy preparing the room because it's all part of the ritual

Friendship spaces are performed and transformed into being, becoming endowed with additional meaning through repetitive ritual [18]. Through regular practice, the pairs generate shared friendship narratives that are inseparable from the improvised spaces where they are played out. Louise reflects here on the longevity of her bond with Anne as a function of the time they have shared on the mat space

Louise: I think we've been doing it seventeen-eighteen years. So that's 700 weeks, two hours a week; 1400 hours. That's a lot of time on the mat.

Narratives emerging from spaces that are shared, especially by female friends, have been referred to as containment stories [19]. These stories emphasise the role of shared proximity in the production of relational experience through shared bodily practice [20]. Hanson \& Pratt [19] note the potential for female 
friendships for transforming spaces into sites of resistance and aspiration. Gendered identities, including aspirations and desires, are fully embedded in -and indeed inconceivable apart from -place [19].

Historically, women's spatial mobility has been limited, choices of living and working spaces curtailed [20]. The transformation of mundane or domestic space (bedrooms, living rooms, cars) into places of companionship, wellbeing, creativity and collaboration reveals an assertive place making that draws on routine practice. Central to this construction of emplaced meaning is the notion that shared spaces are safe places to talk [20].

\section{Conclusion and Discussion}

This project explores the nature of friendship using a method that incorporates the ethics of friendship [13]. This enabled the collection of rich, multisensory data that highlights three themes. It is argued here that the present research has shown friendship to be practice-based, routinized, and emplaced.

These themes resonate with the work of other researchers, yet they also raised further questions. Our first theme, emphasizing friendship as a practice based phenomenon, takes us beyond Rawlins [1] definition of friendship as primarily a means of support and care. Rather, like Tillman [3], the friendship explored here depended on routine activity $[6,21]$. It is acknowledged here that the explicit aims of Louise and Anne's meetings were not to practice friendship, but to practice yoga and enhance wellbeing from Ashtanga practice. Nevertheless, there is clear evidence from our interviews that sustained yoga practice has sustained practice based friendship along the way.

Likewise, Louise and Anne's regular meetings led to our finding about the routine, mundane nature of friendship bonds, and in turn to neglect another characteristic of friendship that has been noted elsewhere; namely, its sporadic, life-event based nature [8]. The next theme, concerning spaces of friendship, showed that our female friendship pair were left to transform spaces (often physically) into places of affiliation where their bonds could be enacted. Engagement in long-term friendshipethnography can yield new ways of thinking, feeling and relating that can lead to deepening understanding on the part of participants, of one's own relationships and practices. Here Anne reveals how she benefited from the research experience

Anne: It was really interesting to see myself practising yoga, so in terms of the finished result it was really lovely to see it and I really like the way you did it

The research presented here highlights the importance of yogic as a practice of friendship, cementing a bond between two friends through regular practice and the development of emplaces meaning.

\section{Conclusion}

To conclude, we must consider the potential limitations and pitfalls facing the qualitative researcher in the form of the obligations of researcher and friend, and how these pitfalls were addressed.

Firstly, whilst striving to maintain existing friendship relationships there remains a professional obligation to offer a full account to participants. Such pitfalls are characteristic of the more equal power balance that exists in friendship ethnography, compared with more traditional fieldwork methods. The equity of power and heightened reciprocity of friendship ethnography are exemplified by an obligation to return outputs to the participants for critique. Tillman [3] took her writings back to her community of study for comment. Follow-up interviews were conducted, inviting reflections.

Second, we note the challenge of maintaining two modes of communication (researcher and friend). Negotiating boundaries is part of all human relations, including research related-baseed ones [22]. Keeping too much distance can compromise rapport. Too much proximity can endanger the research by producing a merger with a participant. Tillman [3] articulates the dilemma. Historically, researchers and participants in social science have been knottily entangled [10]. Indeed, the very claim of a researcher to investigate and write about an 'other' person is to deny, rather than engage with, hyphens of inter-subjectivity that bind us all together. We argue here that it is beneficial to acknowledge and work this hyphen by stepping across the line that divides us from our research participants. We concur with Fine [10], who argues that operating overtly across boundaries between researchers and participants yields rich data [23-45].

\section{References}

1. Rawlins W (1992) Friendship matters: communication, dialectics, and the life course. Aldine de Gruyter, New York, USA.

2. Owton H, Allen Collinson J (2014) Close but not too close: friendship as method(ology) in ethnographic research encounters. Journal of Contemporary Ethnography 43(3): 283-305.

3. Tillmann L (2015) Friendship as method. In: Tillmann L (Ed.), Solidarity: friendship, family, and activism beyond gay and straight. Routledge, New York, USA, pp. 287-319.

4. Roseneil S, Budgen S (2004) Editorial introduction: beyond the conventional family. Current Sociology 52(2): 127-134.

5. Pahl R, Spencer L (2004) Personal communities: not simply families of "fate" or "choice".' Current Sociology 52(2): 199-221.

6. Heaphy B, Davies K (2012) Critical friendships. Families, Relationships and Societies 1(3): 311-326.

7. Pahl R (2000) On Friendship. Polity Press, Cambridge, USA. 


\section{Journal of Yoga and Physiotherapy}

8. Cherry K (1996) Ain't no grave deep enough. Journal of Contemporary Ethnography 25(1): 22-57.

9. Iversen R (2008) Getting Out in Ethnography. A seldom told story.

10. Fine M (1998) Working the hyphens: reinventing self and other. In Denzin N, Lincoln Y (Eds.), The Landscape of Qualitative Research Theories and Issues. Thousand Oaks, USA.

11. Bakhtin M (1986) Speech genres and other late essays. University of Texas Press, Austin, USA.

12. Rivoal I, Salazar N (2013) Contemporary ethnographic practice and the value of serendipity. Social Anthropology 21(2): 178-185.

13. Healy LT (2001) Between gay and straight: understanding friendship across sexual orientation. Alta Mira, Walnut Creek, USA.

14. Gilligan C (2008) Moral orientation and moral development. In: Bailey A, Cuomo C (Eds.), The Feminist Philosophy Reader. McGraw Hill, New York, USA, pp. 46-57.

15. Held V (2006) The Ethics of Care: Personal, Political, Global. Oxford University Press, Hyderabad, India.

16. Jois Pattabhi K (2005) Sūryanamaskāra. Ashtanga Yoga, New York, USA.

17. Braun V, Clarke V (2006) Using thematic analysis in psychology. Qualitative research in psychology 3(2): 77-101.

18. Cresswell T (2004) Place: A Short Introduction. Blackwell, London.

19. Hanson S, Pratt G (1995) Gender, work and space. Routledge, London.

20. Green E (1998) Women doing friendship: an analysis of women's leisure as a site of identity construction, empowerment and resistance. Leisure Studies 17(3): 171-185.

21. Shepard B (2014) Community projects as social activism: from direct action to direct services. Sage, Thousand Oaks, CA, USA.

22. Frank AW (2005) What is dialogical research and why should we do it? Qual Health Res 15(7): 964-974.

23. Appadurai A (1986) The Social Life of Things: Commodities in Cultural Perspective. Cambridge University Press, London.

24. Anderson D (2001) Losing friends. Social Affairs Unit, London.

25. Angrosino M (1998) Opportunity house: ethnographic stories of mental retardation. Alta Mira Press, Walnut Creek, CA, USA.

26. Bunsell $\mathrm{T}$ (2013) Strong \& Hard Women. Routledge, London.

27. Butler T (2006) A Walk of Art: The potential of the sound walk as practice in cultural geography Social and Cultural Geography 7(6): 889-908.
28. Butler T (2007) Memoryscape: How audio walks can deepen our sense of place by integrating art, oral history and cultural geography. Geography Compass 1(3): 360-372.

29. Etherington $\mathrm{K}$ (2007) Ethical research in reflexive relationships. Qualitative Inquiry 13(5): 599-616.

30. Geertz C (1973) The Interpretation of Cultures. New York, USA.

31. Haraway D (1988) Situated knowledges: the science question in feminism and the privilege of partial perspectives. Feminist Studies 4(13): 575-599.

32. Harper D (2002) Talking about pictures: a case for photo elicitation. Visual Studies 17(1): 13-26.

33. Howes D (2005) Empire of the Senses. Berg, Oxford, England.

34. Langdridge D (2013) Introduction to Research Methods and Data Analysis, Pearson, London.

35. MacDougall D (2006) The corporeal image: film, ethnography and the senses. Princeton, Princeton, USA.

36. Pink S (2007) Doing Visual Anthropology. Sage, London.

37. Pink S (2008) An urban tour: the sensory sociality of ethnographic place-making. Ethnography 9(2): 175-196.

38. Pratt M (1992) Fieldwork in common places. In: Jand Marcus GC (Ed.), Writing Culture. University of California Press, California, USA.

39. Simon G (2013) Relational ethnography: writing and reading in research relationships. Forum Qualitative Sozialforschung/Forum: Qualitative Social Research 14(1): 1-13

40. Spradley J (1979) The Ethnographic Interview. London, p. 247.

41. Titchkosky T (2007) Reading and writing disability differently: the textured life of embodiment. University of Toronto Press, Toronto, Canada.

42. Werking K (1997) We're just good friends: women and men in nonromantic relationships. Guilford Press, New York, USA.

43. Whyte W (1993) Street corner society: the social structure of an Italian slum. University of Chicago Press, Chicago, IL, USA.

44. Winlow S, Hall S (2009) Living for the weekend: youth identities in north east England. Ethnography 10(1): 91-113.

45. Young M, Willmott P (1961) Family and kinship in East London. Penguin, Harmondsworth, England.

\section{Your next submission with Juniper Publishers} will reach you the below assets

- Quality Editorial service

- Swift Peer Review

- Reprints availability

- E-prints Service

- Manuscript Podcast for convenient understanding

- Global attainment for your research

- Manuscript accessibility in different formats

( Pdf, E-pub, Full Text, Audio)

- Unceasing customer service

Track the below URL for one-step submission https://juniperpublishers.com/online-submission.php 